\title{
LITHIUM ABUNDANCES IN INCLUSIONS IN DIAMONDS FROM THE UPPER AND LOWER MANTLE
}

\author{
H.-Michael Seitz ${ }^{1,2}$, Gerhard P. Brey ${ }^{1}$, Thomas Stachel ${ }^{1,3}$ and Jeff W. Harris ${ }^{4,1}$ \\ ${ }^{1}$ University of Frankfurt, Germany; ${ }^{2}$ University of Heidelberg, Germany; ${ }^{3}$ University of Alberta, \\ Edmonton, Canada; ${ }^{4}$ University of Glasgow, UK.
}

\section{INTRODUCTION}

Mineral inclusions in diamonds are well kept samples of the earth interior. They were incorporated at the time and place of diamond formation and carry direct information on the chemistry, stratigraphy, age and evolution of the lithosphere and asthenosphere, the transition zone and the upper parts of the lower mantle. Peridotitic inclusions carry a signature of partial melting at shallow depth but also of re-enrichment of incompatible elements presumably at the time of diamond formation; eclogite xenoliths and eclogitic inclusions are considered as former basalts or gabbros or as high pressure cumulates of mantle melts, modified by volatile loss and/or partial melting. Re-enrichment during diamond formation is documented (e.g.Taylor et al. 1998; Stachel et al., 2000a,b). Websteritic inclusions have recently been interpreted as hybrid products of partial melts from eclogites reacting with peridotite (Aulbach et al., 2002) and lower mantle inclusions (ferropericlase, $\mathrm{Mg}$ - and $\mathrm{Ca}$-silicate-perovskites) also do not reflect primitive mantle and show enrichment features.

Lithium and its isotopes are useful tracers of various mantle processes as well as subduction related and alteration processes (Seitz and Woodland 2000; Woodland et al. 2002; Tomascak et al. 2002; Hoefs and Sywall 1997). Thus, we extended our previous studies on $\mathrm{Li}$ concentrations in mantle samples to inclusions in diamonds from the upper and lower mantle. The aim of the study is to obtain an understanding of the partitioning behaviour of $\mathrm{Li}$ between mineral phases from the upper to lower mantle pressure regimes and to get first insights into bulk $\mathrm{Li}$ contents in major mantle reservoirs. Analyses of $\mathrm{Li}$ were carried out using a modified CAMECA 3f-IMS ion microprobe at the Mineralogisches Institut, Universität Heidelberg.

\section{RESULTS AND DISCUSSION}

Altogether 44 mineral grains from 20 diamonds (10 peridotitic, 5 eclogitic, 3 websteritic and 2 lower mantle) were selected for lithium analysis from a sample pool previously characterized by Stachel et al. (2000a,b and ref. cited) and Aulbach et al. (2002).

\section{Peridotitic paragenesis (Fig. 1)}

The Li content of one olivine inclusion from Guinea ( $G$ 201) exceeds the value for olivine from spinel lherzolite $\mathrm{SC1}$ (as reference for a primitive mantle, Jagoutz et al. 1979) by more than one third (2.2 ppm versus $1.6 \mathrm{ppm})$, all other olivines are lower. Clinopyroxenes are significantly lower than those from primitive xenoliths, but garnets are in the same range. With one exception lithium correlates negatively with forsterite content in olivine. Since this is an indicator of the degree of melt depletion of peridotite lithium also simply reflects an earlier depletion event in a peridotitic protolith. While REE-patterns in coexisting garnet and/or clinopyroxene show metasomatic overprint, the Fo-Li-correlation shows that $\mathrm{Li}$ is not transported by a metasomatic agent accompanying or causing diamond growth. This is in contrast to the findings in Australian spinel peridotite xenoliths where lithium was enriched preferentially in olivine presumably by a carbonatitic agent (Seitz \& Woodland 2000). The high partition coefficients $\mathrm{D}^{\mathrm{ol} / \mathrm{cpx}}$ of 5-7 for the diamond inclusions (as compared to 1.62) are not due to disequlibrium between ol and cpx but due to the higher pressure experienced by the inclusions in diamond. Similarily, partition coefficients $\mathrm{D}^{\mathrm{cpx} / \mathrm{grt}}$ are also lower for diamond inclusions at around 3 than for garnet xenoliths from Vitim, Pali Aiki and Kenya with $11-16$.

\section{Websteritic paragenesis}

Websteritic inclusions were analysed in three diamonds from Venetia (Fig. 1).

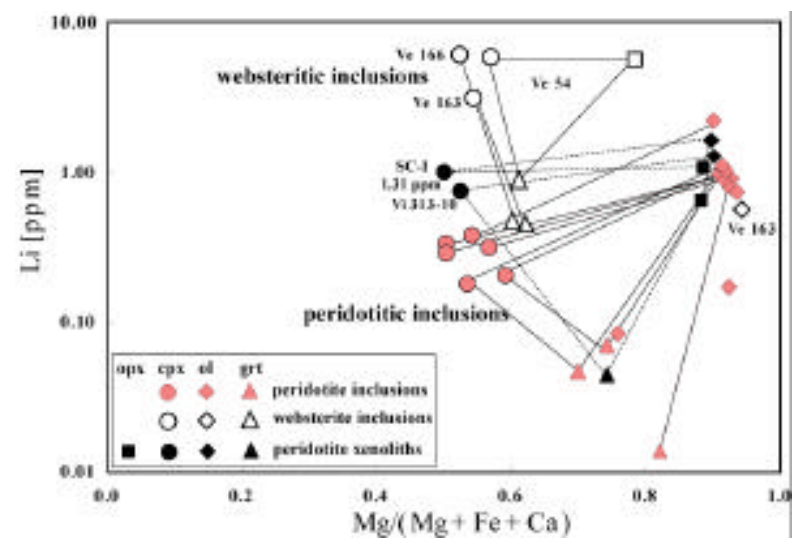

Figure $1 \mathrm{Li}$ versus $\mathrm{Mg} /(\mathrm{Mg}+\mathrm{Fe}+\mathrm{Ca})$ for peridotitic and websteritic diamond inclusions. Coexisting phases are linked by lines. Abundances in minerals from spinel lherzolite SC-1 and in a fairly primitive garnet peridotite from a rift setting (Vi 313-10; Vitim, Lake Baikal, Ionov et al. 1993) are plotted for comparison. 
Clinopyroxenes and garnets have higher $\mathrm{Li}$-contents than peridotitic and also eclogitic inclusions (compare Fig. 2) and diamond VE 54 contains opx with very high lithium contents (compared to the peridotitic paragenesis).

\section{Eclogitic paragenesis and majorite}

Eclogitic inclusions (Fig. 2) were analysed from Kankan (3) and from Venetia (2) whereby two of the Kankan diamonds contain majoritic garnets. Li-contents in clinopyroxene and garnet in general overlap with the peridotitic inclusions and with eclogitic xenoliths, but are much lower than in those from orogenic eclogites. One set of clinopyroxene-garnet inclusions (VE 176) has low and very similar Li-abundances and also partition coefficients in the range of most eclogite xenoliths analysed by Woodland et al. (2002), two further cpx-grt pairs (VE 160 and KK 96) have much higher lithium contents than most eclogite xenoliths and also the websteritic inclusions. Their $\mathrm{Li}$ and also $\mathrm{D}^{\mathrm{cpx} / \mathrm{grt}}$ are, however, similar to a xenolith from Jagersfontein (Ja 4) which approaches orogenic eclogites in composition (Fig. 2). Most eye-catching is the drastic change in the behaviour towards lithium of garnet with a majorite component compared to that of a pure garnet. Partition coefficients $\mathrm{D}^{\mathrm{cpx} / \mathrm{grt}}$ are $3-7$ and $\mathrm{D}^{\mathrm{cpx} / \mathrm{maj}}$ around 1. The analysis of a single majoritic inclusion by Kaminsky et al. (2001) also gave a high value of about $8 \mathrm{ppm}$. Since the majoritic component in garnet is strongly pressure dependent, this may also be the case for lithium.

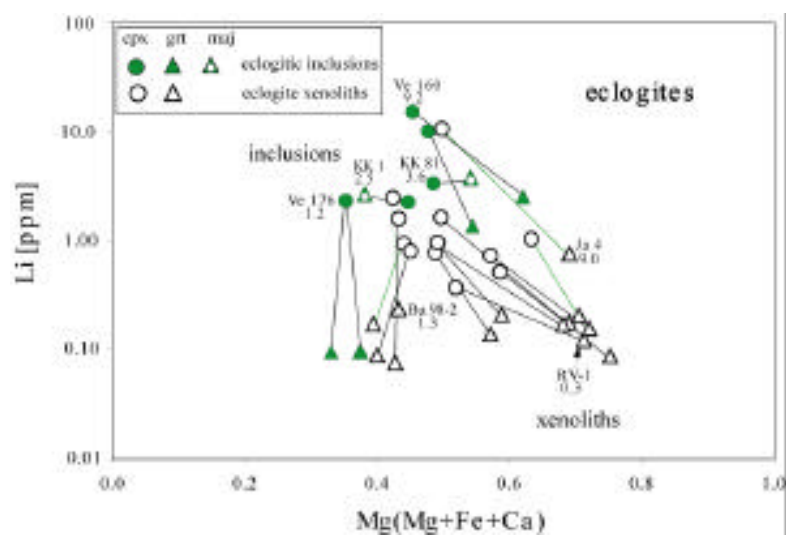

Figure 2: $\mathrm{Li}$ versus $\mathrm{Mg} /(\mathrm{Mg}+\mathrm{Fe}+\mathrm{Ca})$ for eclogitic diamond inclusions. Eclogite xenoliths data from Woodland $₫$ al. (2002) are plotted for comparison. Estimated bulk Li abundances of the bulk rock are shown underneath the sample numbers.

\section{Lower mantle inclusions (Fig. 3)}

Coexisting ferropericlases and MgSi-perovskites were analysed from two diamonds from Guinea. Ferropericlase is very high in lithium with 38.7 and $49.5 \mathrm{ppm}$, while coexisting Mg-perovskite is extremely low (0.068 and $0.095 \mathrm{ppm})$. These values are even higher than those reported by Kaminsky et al. (2001) for ferropericlase from Brazil. These authors also give values for two Ca-perovskites with 2.5 and $50.5 \mathrm{ppm}$. The very different behaviour of $\mathrm{Li}$ in ferropericlase and in Mg-perovskite may be explained in a similar way as that in olivine compared to garnet. Magnesium is in octahedral sites in ferropericlase and lithium can substitute for $\mathrm{Mg}$ with $\mathrm{Al}$ replacing a second $\mathrm{Mg}$ for charge balance. $\mathrm{Mg}$ is 8 -fold coordinated in perovskite and $\mathrm{Li}$ does not enter this site.

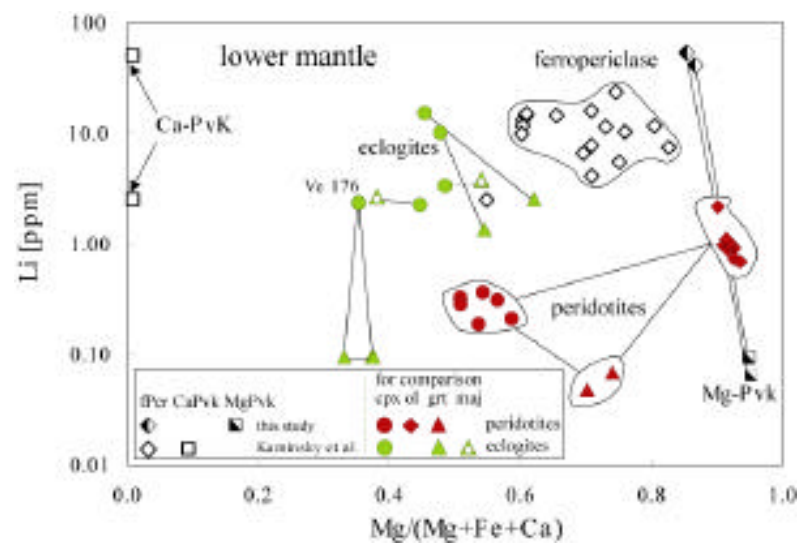

Figure 3: $\mathrm{Li}$ versus $\mathrm{Mg} /(\mathrm{Mg}+\mathrm{Fe}+\mathrm{Ca})$ diagram for lower mantle diamond inclusions. Inclusions from the Juina area Brazil (Kaminsky et al., 2001) as well as eclogite and peridotite inclusions from this study are shown for comparison.

\section{LITHIUM ABUNDANCES IN THE UPPER AND LOWER MANTLE}

Considerable variations can be observed in the abundances within and between the peridotitic, websteritic and eclogitic groups. Olivine is the major carrier of $\mathrm{Li}$ in peridotites and the observed correlation between Fo- and Li-contents establishes $\mathrm{Li}$ as a proxy for the degree of previous melt depletion. We have calculated possible bulk rock compositions of the peridotite diamond sources based on assumed modal abundances. This gives $1.4 \mathrm{ppm}(\mathrm{G} 201)$ similar to that of an estimated primitive mantle (e.g. Jagoutz et al., 1979) all others are depleted to various extents.

Bulk estimates for websterites are based on a rock that contains ortho- and clinopyroxenes in equal amounts and $2 \%$ garnet. They are higher than for peridotites with 3.1 to $5.8 \mathrm{ppm}$ and lie between bulk estimates for orogenic eclogites and estimates for most eclogite xenoliths. These relative amounts are consistent with an origin of the websterites as products of hybridisation of peridotite through a melt from eclogite pods as suggested e.g. by Aulbach et al. (2002).

Bulk estimates for eclogites were made by assuming grt:cpx $=50: 50$, also for those with majoritic garnet. Interestingly, the two inclusions pairs with majoritic garnet from a depth close to the transition zone have 
similarly low bulk lithium as the more common group of eclogite xenoliths.

The lower mantle samples do not show lithium depletion nor abundance levels similar to primitive mantle. Lithium rather shows an enrichment of 4 to 5 times relative to primitive mantle. Our data of high $\mathrm{Li}$ in ferropericlase are supported by similar values reported by Kaminsky et al. (2001). The high lithium values may be the result of some form of $\mathrm{Li}^{-}$ metasomatism in the lower mantle or a memory of some kind of low temperature alteration in an ocean floor environment whereby this diamond protolith was later subducted into the lower mantle with the Lisignature being preserved.

\section{REFERENCES}

Aulbach, S., Stachel, T., Viljoen, K.S., Brey, G.P., Harris, J.W., 2002. Eclogitic and websteritic diamond sources beneath the Limpopo Belt - is slab-melting the link? Contributions to Mineralogy and Petrology 143, 56-70.

Hoefs, J., Sywall, M., 1997. Lithium isotope composition of Quaternary and Tertiary biogen carbonates and global lithium isotope balance. Geochimica et Cosmochimica Acta, 61(13): 2679-2690.

Ionov, D.A., Ashchepkov, I.V., Stosch, H.-G., WittEickschen, G. and Seck, H.A., 1993. Garnet peridotite xenoliths from the Vitim Volcanic Field, Baikal Region: the nature of the garnetspinel peridotite transition zone in the continental mantle: Journal of Petrology, 34: 1141-1175.

Jagoutz, E., Palme, H., Baddenhausen, H., Blum, K., Cendales, M., Dreibus, G., Spettel, B., Lorenz, V., Wänke, H., 1979. The abundances of major, minor and trace elements in the earth's mantle as derived from primitive ultramafic nodules. Proc. Lunar Planet. Sci. Conference 10th: 2031-2050.

Kaminsky, F.V., Zakharchenko, O.D., Davis, R., Griffin, W.L., Khachatryan-Blinova, G.K., Shiryaev, A.A., 2001. Superdeep diamonds from the Juina area, Mato Grosso State, Brazil. Contributions to Mineralogy and Petrology, 140, 734-753.

Stachel, T., Brey, G.P., Harris, J.W., 2000. Kankan diamonds (Guinea) I: from the lithosphere down to the transition zone. Contributions to Mineralogy and Petrology 140, 1-15.

Stachel, T., Harris, J.W., Brey, G.P., Joswig, W., 2000. Kankan diamonds (Guinea) II: lower mantle inclusion parageneses. Contributions to Mineralogy and Petrology, 140, 16-27.

Taylor, L.A., Milledge, H.J., Bulanova, C.P., Snyder, G.A. and Keller, R.A., 1998. Metasomatic eclogite diamond growth: evidence from multib le diamond inclusions. Int. Geol. Rev., 42, 959-983.
Tomascak, P.B., Widom, E., Benton, L.D., Goldstein, L.D., Ryan, J.G., 2002. The control of lithium budgets in island arcs. Earth and Planetary Science Letters 196(3-4), 227-238.

Seitz, H.-M., Woodland, A.B., 2000. The distribution of lithium in peridotitic and pyroxenitic mantle Lithologies - an indicator of magmatic and metasomatic processes. Chemical Geology, 166, 47-64.

Woodland, A.B., Seitz, H.-M., Altherr R, Marschall, H., Olker, B., Ludwig, T., 2002. Li abundances in eclogite minerals: A clue to a crustal or mantle origin? Contributions to Mineralogy and Petrology, 143, 587-601

Contact: H.-Michael Seitz, Institut für Mineralogie, Universität Frankfurt, 60054 Frankfurt, Germany, e-mail: H.M.Seitz@ em.uni-frankfurt.de 